\title{
BIM w zintegrowanym procesie projektowym
} BIM in the integrated design process

\begin{abstract}
Streszczenie
Dynamicznie rozwijający się świat, wymaga efektywnych narzędzi projektowych. Pracujemy szybciej, tworzymy budynki wyższe, bardziej zaawansowane technologicznie dokumentując jednocześnie każdy detal bardziej kompleksowo niż dotychczas. Na skutek tego biura projektowe wdrażają narzędzia, które pozwalają optymalizować proces projektowy, zarządzać zespołem i dokumentacją oraz cyklem życia budynku w wydajniejszy sposób. Rozwój technologii BIM (Building Information Modeling) sprawia, iż budynki XXI wieku tworzone są przy użyciu oprogramowania do projektowania wielowymiarowego 6-7D. Przy użyciu definiowanych parametrycznie multidyscyplinarnych baz danych, zawierających pełną informację o strukturze, materiale, instalacjach czy konstrukcji, projektuje się precyzyjnie, a wszelkie kolizje wykrywa już na wstępnym etapie prac projektowych nie zaś na placu budowy. Analizy, badania i autorskie rozwiązania architektoniczne harmonizowane są z branżą konstrukcyjną, instalacyjną, uwzględniając proces budowy, działania i starzenia się obiektu, aż do momentu jego utylizacji w ramach zintegrowanego procesu projektowego.
\end{abstract}

\begin{abstract}
The dynamically developing world requires effective design tools. We work faster; we create buildings that are taller and more technologically advanced, while at the same time documenting every detail more comprehensively than ever before. As a result, design offices implement tools that allow them to optimize the design process, manage the team, documentation, and the building's life cycle in a more efficient way. The development of the BIM (Building Information Modeling) technology means that the 21st-century buildings are made using software for 6-7D interdisciplinary design. By using parametrically defined interdisciplinary databases containing complete information about the structure, materials, installations or construction, the design process is precise and all clashes are detected at the initial stage of design works rather than at the construction site. Analyzes, research, and proprietary architectural solutions are harmonized with the construction and installation industries, taking into account the process of construction, operation and aging of the facility, until its utilization as part of the integrated design process.
\end{abstract}

Słowa kluczowe: BIM, architektura, konstrukcja, projektowanie wielobranżowe Keywords: BIM, architecture, construction, interdisciplinary design

Wraz z dynamicznym rozwojem technologii oraz projektowania zintegrowanego niezbędna okazała się zmiana modelu funkcjonowania współczesnego biura projektowego. W latach 80. XX wieku wiele pracowni architektonicznych, mających potrzebę nadążania za nadchodzącymi zmianami i postępującą komputeryzacją świata zachodniego, zaimplementowała proces projektowy wspomagany systemami typu CAD. Wiązało się to ze zrezygnowaniem z kreślenia odręcznego i przyswojeniem obsługi programów pozwalających na rysowanie w przestrzeni wirtualnej.

Zmiana ta istotnie wpłynęła na szybkość wykonywanej pracy. Dokładność rysunku technicznego wzrosła niewyobrażalnie, bowiem w wirtualnej przestrzeni rysunku nie istniały narzucone ograniczenia wynikające ze skali, a rysunki można było powiększać dosłownie w nieskończoność. Technologia ta była jednak tylko zamianą deski kreślarskiej na jej wirtualny odpowiednik, projekt nadal powstawał jak przed latami, linia po linii zamieniając każdy kreślony kiedyś punkt, na komputerowe wzory matematyczne definiujące linie i wektory.
With the rapid development of technology and integrated design, it was necessary to change the model of the functioning of a contemporary design office. In the 1980s, many architectural offices that had a need to keep up with the upcoming changes and the ongoing computerization of the Western world implemented a design process supported by CAD systems. This meant a departure from drawing plans by hand and a need to learn how to operate software that allows for drawing in virtual space.

This change significantly affected the speed of work. The accuracy of technical drawings increased unimaginably because in the virtual space there were no limitations resulting from the scale, and the drawings could be enlarged literally indefinitely. This technology, however, was merely a replacement of the drawing board with its virtual equivalent; the designs continued to be created as in the previous years, line by line replacing each point that was once drawn by hand with comput- 
W 1963 roku prawdziwą burzę wywołało oprogramowanie chine Graphical Communication System" opracowane w Lincoln Labs MIT obsługujące 4 rzutnie i widok trójwymiarowy, prekursor dzisiejszych systemów CAD (ang. Computer Aided Design)

Początkowo, używana jedynie eksperymentalnie, technologia modelowania za pomoca definiowania parametrów przegród struktur budowlanych i dynamicznych brył dopiero 40 lat później podbiła rynek i na stałe zagościła w biurach projektowych całego świata.

Zaawansowany rozwój technologii we współczesnym świecie sprawit, iż projekty architektoniczne tworzone są nie tylko w systemach CAD, umożliwiających przeniesienie zamysłu projektowego na elektroniczne rzutnie programu komputerowego, ale również przy użyciu oprogramowania do projekwego, ale również przy użyciu oprogramowania do projektowania wielowymiarowego i w oparciu o metodologię BIM
(Building Information Modeling). Projekty XXI wieku to nie tylko skomplikowane modele 3D, ale multidyscyplinarne bazy tylko skomplikowane modele 3D, ale multidyscyplinarne bazy
danych, systemy zależności między elementami, zbiory indanych, systemy zależności między elementami, zbiory in-
formacji, bibliotek definiowanych parametrycznie, osadzone formacji, bibliotek definiowanych parametrycznie, osadzone w czasie (4D) , powiązane z kosztami (5D), zapotrzebowaniem
na energie (6D) i pełniące role centrów zarzadzania życiem na energię (6D) i pełniące rolę centrów zarządzania życiem budynku (7D) od jego powstania do śmierci technicznej. Ta ewolucja systemu projektowania dotyczy rowniez wszystkich branż, tj. konstrukcyjnej, sanitarnej czy elektrycznej. Przy użyciu elementów zawierających pełną informację o składowych projektu, w zakresie instalacji czy konstrukcji przewidziec można bardzo precyzyjnie nie tylko kolizje, które trudno wykryć podczas projektowania metodami tradycyjnymi na podstawie rysunku dwuwymiarowego ale też prace konstrukcji, działanie instalacji oraz koszty ich realizacji. Dodatkowo na etapie projektu możliwe jest zarządzanie również procesem ich wymiany lub modernizacji po latach użytkowania.

Projektowanie wielowymiarowe w technologii BIM (ang. Building Information Modeling - modelowanie informacii o budynkach i budowh) jest niezukte szybki i fektywn Charakteryzuje je wysoki stopien automyzacii, sprzywe. climinowz bón projektowch. Zmiany które przjajacy ze soba p ciu o Bum wym waj rew me

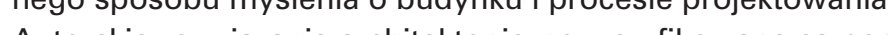
Autorskie rozw azzina archude kątem mozliwości konstrukcyjnych w ramach wspólnego oprogramowania do projektowania a poprawność tras instalacji i zalożon branzowych kontrolowad možna w ramach spojnego modelu IFC. Umieszczenie całego procesu tworzenia dokumentacji projektowej w jednym miejscu, spójnej z częścią branżową, daje możliwość badania wpływu i relacj zachodzących między składowymi zależności, a takie działanie daje projektantom szeroką wiedzę na temat cyklu życia projektowanych przez nich budynków.

W przypadku tradycyjnego projektowania architektonicznego obiekty budowlane powstają za pomocą struktur, powierzchni i elementów, których atrybuty, układy, wspólne powiązania i zasady działania określa projektant. Wirtualny model budynku zawiera nie tylko trójwymiarową bryłę, ale również er's mathematical formulas that define lines and vectors.

In 1963, software developed by Ivan Sutherland became a global sensation. "Sketchpad, A ManMachine Graphical Communication System", deviewports as well as a three-dimensional view, was the precursor of today's CAD (computer-aided design) systems.

Initially only used experimentally, the technology of modeling by defining parameters of partitions building structures and dynamic shapes conquered
the market and got a permanent foothold in design the market and got a permanent footh
offices around the world 40 years later.

Offices around the world 40 years later.
The advanced development of technology in the The advanced development of technology in the
modern world has caused it so that architectura designs are created not only in CAD systems that enable the transfer of a design concept to electronic viewports of a computer program but also using software for multidimensional design and based on the BIM (Building Information Modenot just complicated $3 \mathrm{D}$ models but interdisciplinary databases, systems of dependencies between elements, sets of information, parametric libraries, which are time-stamped (4D), associated with costs $(5 \mathrm{D})$, energy demand (6D) and acting as centers for managing the building's life cycle (7D) from its inception to technical death. This evolution of the design system also applies to all industries, i.e. elements containing complete information use the components of the project in terms of installation or construction, it is possible to very precisely predict not only clashes that are difficult to detect with traditional design methods based on a twodimensional drawing, but also how the structure will work, how the installations will function and ditionally, it is also possible to manage the proces of their replacement or modernization after years of use at the design stage.

Multidimensional design in BIM (Building Information Modeling) technology is extremely fast and effective. It is characterized by a high degree of au tomation, which helps to eliminate design errors. the BIM-bes bresign mo the a lution in design, an implementation of a differen about the building and the desig process.

Proprietary architectural solutions are verified in terms of structural capabilities within the commo design software, and the correctness of installation within a consistent IFC model. Placing the entire process of creating project documentation in one place, consistent with the industry section, gives the opportunity to study the impact and relationships between components of a dependency, and acting this way gives designers a wide range of knowledge about the life cycles of the building they design.

struction objects are created by means of contures, surfaces and elements whose attributes, całą bazę danych informacji niegeometrycznych o elementach w nim użytych, o projekcie, o jego strukturze cyklu życia i sposobie funkcjonowania.

W przypadku projektowania wielowymiarowego konstrukci dodatkowa informacją, którą niesie ze sobą model, są nie tylko same modele: statyczne i dynamiczne, wielowymiarowe modele elementów stalowych, drewnianych, czy żelbetowych umożliwiajaca ich automatyczną prefabrykacje na maszynach CNC, ale przede wszystkim ich zachowanie, sposób realizaci prac i ich wartość kosztorysowa. prac i ich wasc kosztorysowa. Modelując złożony system powiaz hon wplyw na zaprojektowana wczesn wply no zojón

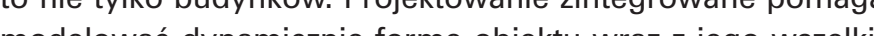
mi ska dy mi oraz ba mi skla dowy mi oraz ba foc ich wplyw na bryle i poszukiwac ostatecznym wyglądem i charakterem projektowanej formy.

W przypadku projektowania tradycyjnego, między konstrukcją a inżynierią sanitarną oraz elektryczną powstawały kolizje. których nie sposób było uniknąć. Bez modelu zawierającego informację o całej konstrukcji budynku, jej charakterze, kszta cie, wielkości i częściach składowych, kolizje wykrywane zo stawały w późnym etapie wykonawczym bądź na placu budowy.

Dzięki możliwości dodania wszelkich branż do procesu modelowania wielowymiarowego w przypadku projektowania złożonych budynków uwidacznia się skomplikowana sieć pofączeń i zależności między nimi, a program pomaga projektantowi w zachowaniu ich efektywnego rozplanowania i zapewnienia poprawnego działania.

Obecnie algorytmy programu interpretują każdą zmiane pokazując jej wpływ na pozostałe elementy budynku, każd przesuniecie elementu na modelu, w którym wyszczegól dione sa branzie oraz ich wptyw na pozostałe elementy. Funkcja sprawdzania modelu i wyszukiwania błedów pozwa Funkcja wizje miejsc newralgicznych i bezpośrednia reakcje w pa reprzeprojektowania w locie oznaczonego miejsca.

Cyfrowy model zintegrowany jest $z$ rysunkami płaskimi i pocy rowy mozwala dy mo

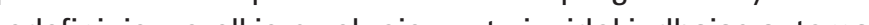
redefiniuje wszellie przekroje, zzu i widoki, dbając automatycznie o pelną spojnosc projektu. W takich warunkach pracy architekt może skupić się na procesie tworzenia formy, gdy z program dba o ins związanych z designem.

Opierając się na bazie danych modelu jednostka obliczeniowa tworzy, rysunki, detale, spisy zawartości dla każdej z branż. W przypadku architektury są to nie tylko zestawienia powierzchni, ścian, podłóg, materiałów, czy wyposażenia, ale też dyscypliny wpływające na funkcjonalność środowiska zbudowanego, przez integrację ludzi miejsc i procesów, tzw. Facility Management.

Konstrukcja zawiera w sobie informację o ilości zużytych materiałów, siłach działających w całym obiekcie, relacjach między elementami zaprojektowanymi. Branża sanitarna to ze- configurations, common associations and principles of operation are determined by the designer. The virtual model of a building contains not only a three-dimensional solid but also the entire database of non-geometric information about the eleture and the way it functions.

In the case of the multidimensional design of a structure, the additional information provided by the model are not only static and dynamic models but also multidimensional models of steel, wood en or reinforced concrete elements that enable their automatic prefabrication on CNC machines, carrying out works and their estimated value. By modeling a complex system of structural connections in a new, yet unused system, its impact on the previously designed architecture can be seen in real time. This applies not only to buildings. In tegrated design helps to dynamically model the form of an object with all its components, to exam and look for alternative solutions. This improves the control over the final appearance and character of the designed form.

Traditional design was causing clashes between the structure and the sanitary and electrical en gineering which could not have been avoided. Without a model containing information about the entire structure of the building, its character, detected at a late stage of execution or at the construction site.

Thanks to the ability to add all industries to the multidimensional modeling process, in the case of designing complex buildings, a complicated nework of connections and relationships between them become visible, and the software helps the their proper functioning. Currently, the algorithms of the software interpret each change, displaying its impact on the other elements of the building, each shift of an element on the model in which the industries and their impact on the other elements are specified. The feature of inspecting the model and searching for errors alby redesigning the marked place on the fly.

The digital model is integrated with flat drawings and allows for dynamic generation of flat documentation on its basis. After making changes, the software instantly re-defines all cross-sections, projections, and views, automatically ensuring
full consistency of the project. In such conditions, full consistency of the project. In such conditions,
the architect can focus on the process of creating a form because the program takes care of the inteare not related to design

Based on the model's database, the processing unit creates drawings, details, and lists of contents for each industry. In the case of architecture, these are not only breakdowns of surfaces, walls, floors materials, or equipment, but also disciplines that
affect the functionality of an environment built by the integration of people, places, and processes, so-called Facility Management. 
stawienia wentylacji, klimatyzacji, ogrzewania, kanalizacji czy instalacji wodnej oraz ich wpływ na elementy konstrukcyjne. W tej dziedzinie niezwykle istotne jest, że model wielowymiarowy pozwala symulować na etapie projektowym zapotrzebowanie na energię, ciepło i świeże powietrze. Projektowanie elektryczne, teletechniczne czy teleinformatyczne złożonych struktur kablowych pozwala na pełna kontrole nad nimi już na wczesnym etapie jego powstawania i zarzadzania ich serwisem i wymian podobnie jak ma to mieisce w Dubaju cay wisen i wy gdie petna infrastruktura techniczna pod uju czy mians, sieci kanalizaci kaboj i linie zasilajace i przytaczy, jest inwentaryzow

Ten typ projektowania ma ogromną zaletę związaną z pracą zdalna. Modelowanie budynku w grupowej pracy sieciowej zdalną. Modelowanie budynku w grupowej pracy sieciowej
przez dowolnego specjaliste nawet z odległego krańca świata przez dowolnego specjaliste nawet z odległego krańca świata
oraz pełna synchronizacja międzybranżowa pozwala w ciągu kilku chwil na wprowadzenie wszelkich zmian, zarządzanie
nimi i dostep do skupionych informacji wielobranżowych nimi i dostęp do skupionych informacji
w ramach jednego terminala dostępowego.

W ramach jednego terminala dostępowego. Technologia projektowania BIM nie odnosi się jedynie do etapu procesu powstawania budynku wirtualnego czy kontrolowania przebiegu bu
projektowych. To na projektowych. To narzędzie, które pozwala kontrolować cały cykl życia budynku do momentu jego utylizacji. Jest to typ projektowania, ktory integruje wszystkie branże w jeden centralny model. Dzięki generowanym podczas tworzenia projektu bazom danych IFC (Industry Foundation Classes) możliwa jest współpraca między wieloma branżami m.in. konstrukcyjną, sanitarną i elektryczna.

Pliki pełne informacji o zastosowanych obiektach, oparte na systematyce buildingSMART (dawniej International Alliance for Interoperability, IAI), ułatwiają współprace w zakresie architektury, inżynierii, budownictwa i przemysłu.

Ta interoperacyjność sprawia, iż format IFC jest powszechnie stosowane do wymiany informacii miedzy systemami BIM a przeglądarkami modeli, dając jednocześnie pełny dostęp do wszelkich informacji o budynku.

Możliwość wymiany informacji z zewnętrznymi aplikacjami pozwala na stworzenie wirtualnych analiz, dzięki którym już na etapie projektowania odkryć można słabe punkty budynku podwyższające jego energochłonność, wygenerować charakterystykę energetyczną czy przeprowadzić analizę nasłonecznienia, oddziaływania na tereny sąsiednie oraz wpływ necznienia, oddziaływania na tereny sąsiednie oraz wpływ
ciśnienia, wiatrów na budynki wysokościowe ale również ciśnienia, wiatrów na budynki wysokościowe ale rownież
otwiera nowe horyzonty przemyślanego zarządzania czynnikami atmosferycznymi, jak choćby przez gromadzenie wody kami atmosf

Ciaggte doskonalenie modeli, poszerzanie zasobów baz danych, daje możliwości eliminowania słabych punktów i niezwykłe oszczędności czasowo-finansowe.

Dzięki generowanym podczas tworzenia modelu bazom danych IFC (Industry Foundation Classes) możliwa jest współpraca równiez z osobami niezwiązanymi z projektowaniem. Ten uniwersalny typ pliku może zostać odtworzony do przeglądania jego zawartości np. przez urzędników państwowych operatorów, dostaw mediów, ale i samego inwestora etc.
The construction contains information about the amounts of materials used, forces affecting the entire facilty, relations between the designed elements. The sanitary industry covers ventilation, a conditioning, heating, sewage or water installations
and their influence on structural elements. In this field, it is extremely important that the multidimensional model allows for simulation of the demand for energy, heat and fresh air at the design stage. Electrical, telecommunications or ICT design of complex cable structures allows for full control over them at an early stage of their creation as well as case in Dubai or London where the entire technice infrastructure consisting of the cable duct network under the city streets, the power lines and connections is inventoried using multidimensional models. This type of design has a great added benefit of remote work. The ability to model a building collaboratively online and the full interdisciplinary synchronization allow any specialist, even one
located in the far reaches of the world, to make located in the far reaches of the world, to make
any changes, manage them, and access interdisciplinary information within one access terminal in a matter of moments.

The BIM design technology does not merely involve the stage of creating a virtual building or controlling the construction process and eliminating the risk of project inaccuracies. It is a tool that ing until its disposal. It is a type of de of a buildintegrates all industries in one central model. The IFC (Industry Foundation Classes) databases generated during the creation of the project make the cooperation between many industries, including construction, sanitary and electrical, possible. Files full of information about the used objects, based on the buildingSMART (formerly Internafacilitate cooperation in the fields of architecture, engineering, construction, and industry.

This interoperability makes the IFC format widely used for the exchange of information between BIM systems and model browsers while giving full access to all information about the building

The ability to exchange information with externa ses which make it possible at the of virtual analydiscover the weak points of the building that in crease its energy consumption, generate energy characteristics or carry out the analysis of sun exposure, impact on neighboring areas and the influence of pressure, winds on high-rise buildings but it also opens new frontiers for thought-ou management of atmospheric factors, such as th

database resources, gives us the ability to elim nate weaknesses and provides extraordinary time and money savings.

The IFC (Industry Foundation Classes) databases generated during the creation of the model also make it possible to work with people who are no be opened to display its contents, e.g. by government officials, operators, utility suppliers, but also by the investors themselves.
Na ksztaltowanie architektury w oparciu o aktualne wymog komputerowych narzedzi zintegrowanego procesu projektowego, związanych z tworzeniem, organizacją i zarzadzaniem projektem. Jednak to nie wszystko, technologia nie stanow tylko narzedzia w rekku artysty, współczesne systemy zachecają do współpracy projektant-komputer

Według badań przeprowadzonych w Wielkiej Brytanii - NBS National BIM Report 2014 świadomość istnienia technoli wiedzio nie tylko słyszało o istnieniu BIM ale również znało podstawy jego funkcjonowania.

Stało się tak dlatego, że rząd angielski nałożył rozporządzeniem obowiazek wprowadzenia projektowania w standardzie BIM dla każdego biura architektonicznego czy architekta, który zamierza brać udział w przetargach państwowych od 2016 roku.

W Anglii już dzisiaj zawiązała się inicjatywa rządowa Construction 2025: Industrial Strategy for Construction mająca na celu wzmocnienie pozycji Wielkiej Brytanii na rynku budowlanym w skali Europy a nawet świata.

Z podanych statystyk wynika również, że $95 \%$ biur zadeklarowało wprowadzenie standardów metodologii BIM do biur w ciągu najbliższych pięciu lat z czego $54 \%$ respondentów aktualnie wdrożyło już system i używa go w procesie projektowym.

Anna Winstanley i Nigel Fraser z Lean BIM Strategies Limited w swojej pracy pt. BIM for all - dummies or not! scharakteryzowali proces wdrażania technologii BIM oraz określili wymierne korzyści jakie niesie ze sobą implementacja rozwiązan w codziennej praktyce projektowej. Kolejno usystematyzowano korzyści, jakie niesie ze sobą nowoczesna technologia projektowania w hierarchii od najważniejszych w codziennym procesie projektowym, do aspektów fundamentalnych w kontekście długofalowym. Na samym szczycie piramidy znalazty sie zagadnienia takie, jak: szybkie modelowanie Dozliwości wirtuanych spacerów czy rozszerzona izeczypacyca calo mulk staw uplasowaly sie row niez cechy, bez kónch rozwoj biura zarządzanie projektem nie jest možlwe, tj.. Wymiana danych informacji, planowanie zarządzanie procesem projektowym kontrola kosztow, zamowien i czasu realizacil.

Jednocześnie $66 \%$ badanych W Wiekiej Brytanii było zdania ze niedługo wykonawcy zaczną wymagać dostarczania dokumentacji w standardzle BIM i proces będzie i tak nieunikniony. $52 \%$ respondentów uznało, ze uzywanie oprogramowania BIM przyspiesza pracę biura, a zaledwie $4 \%$ uznało, że nie ma potrzeby wdrazania nowego standardu pracy.

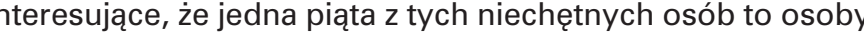
dotychczas nie pracujące w BIM, a jedynie $4 \%$ to osoby, któr projektują za jego pomoca.

Na podstawie powyższych badan wyraźnie widać, że Anglicy w pewien sposób zmuszeni ustawowo do zmiany srodowi-
The shaping of architecture based on current formal and legal requirements is significantly influenced by the use of computer tools used for the integrated design process related to the creect. However, that is not all, technology is not just tool in the hands of the artist - modern systems encourage designer-computer cooperation. According to research conducted in the United Kingdom - NBS National BIM Report 2014, the awareness of the existence of BIM technology mong professionals is close to universal. In 2010 $95 \%$ of them not only heard about the existence of BIM but also knew the basics of its functioning This is because the English Government imposed the regulation with the obligation to implemen BIM design for any architectural office or architect who intends to participate in state tenders from 2016 onward

A government initiative, Construction 2025: Indus en the United Kingdom's position on the construction market in Europe and the whole world has already begun.

The statistics also show that $95 \%$ of offices declared that they will introduce the standards of BIM methodology in the next five years, with $54 \%$ cospondents stating that they have already implecess.

Anna Winstanley and Nigel Fraser from Lean BIM Strategies Limited in their article $B I M$ for all - dummies or not! have characterized the process of implementing the BIM technology and identified

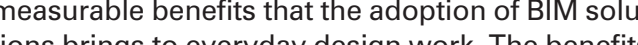
of mongs to everyday design work. The benefits been systematized from the most important the everyday design process to the aspects fundamental in the long-term context. Aspects such as: fast $3 \mathrm{D}$ modeling, photo-realistic visualizations, renderings and animations, virtual walks or augmented reality were placed at the top of the pyrato the entire process of officen to aspects related such as good collaboration, design coordination easier communication and extremely important clash detection. Placed at the bottom were features without which the development of the office ard project management are impossible, i.e. shargata and information, planning, process manAt thent, costing, commissioning and scheduling were of the opinion that sospondents in the UK begin to require the submission of documentalion in the BIM standard and the process would be unavoidable anyway.

nts said that using BIM software speeds up the work of their office and only $4 \%$ think that there is
standard of work.

Interestingly, one-fifth of the reluctant were people who never worked using Bim ben and only $4 \%$ were the people who use it.

Based on the above-mentioned research, it is 
ska projektowego skłonni są raczej docenić zalety sytuacji niż uznac ją za niepotrzebną komplikację i próżną zmiane utartych przez lata schematów.

Reprezentujący Royal Institute of British Architects manager projektu BIM2050 Stefan Mordue twierdzi, iż kluczem do sprawnego wdrażania technologii jest kultura integracji. Słowa te wypowiedziane w kontekście scalenia zespołu związanego $z$ projektem doskonale opisują również samo założenie BIM. W czasie badań zmierzony zostat poziom nastawienia projektantów do koncepcii wdrażania nowych metod pracy-93\% tantow do konce wi wazin nie biura na potrzeby wdrażania BIM wiąze się z redefinicja i zmiana utartych od lat praktyk, zmianą przyzwyczajeń i sformalizowaniem przeply
sochłonny proces.

Kompletne zintegrowanie ze soba branż jest kluczem do twoKompletne zintegrowanie ze soba branż jest kluczem do tworzenia projektow zawierających rozwiązania autorskie, które testowane mogą byc w warunkach rzeczywistości wirtualnej. Wdrażanie i testowanie rwielokrotnionym nakłąadem pracy, gdyż model aktualisię ze zwielokrotnionym nakładem p

zuje wszystkie branże jednocześnie.
Na podstawie powyższych badań wyraźnie widać, że Anglicy Na podstawie powyższych badań wyraźnie widać, że Anglicy w pewien sposób zmuszeni ustawowo do zmiany środowiska projektowego skłonni są raczej docenić zalety sytuacji niż uznać ją za niepotrzebną komplikacje i próżną zmianę utartych przez lata schematów.

Dzięki przeprowadzonej analizie kształtuje się obraz technik BIM mający zrewolucjonizowac system pracy biura projektowego XXI wieku. Miejsca gdzie architekt $z$ wizjonera staje sie managerem odpowiedzialnym za realizację projektu. Architekt przejmuje pełną kontrolę nad każdym etapem procesu inwestycyjnego, poczawszy od etapu koncepcyjnego, poprzez część budowlaną kontrole kosztów i współprace na budowie do koordynacji całego zespołu zaangażowanego $w$ ten proces. Dażenie do pełnego zintegrowania procesu projektowego nie tylko ze względów formalnych ale w szczególności pod wzgledem szybkosci, projektu jawi sie być gwarantem sukcesu na rynku nowo-

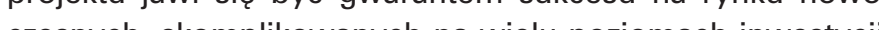
Szczególnie iż, już dzisiaj, takie wymagania zaczynają coraz cześciej do architektów kierować inwestorzy.

Stojąc u progu tak wielkich zmian, które już dziś widoczne sa u naszych sąsiadów, Polska nie chcąc odbiegać od standaru naszych sąsiadów, Polska nie chcąc odbiegac od standarzów na szczeblu ustawowym, adaptować technologie do krajowych realiów. W przeciwnym razie polscy projektanci moga znaleźć się w sytuacji, w której nie będą w stanie konkurować $z$ nowoczesnym modelem projektowym nie tylko ze względów formalnych, ale w szczególności pod względem szybkości, dokładności i zakresu wykonywanego projektu.

W Polsce wielu architektów dało już szansę technologii opartej na standardach BIM, jednak gdy zachodzi potrzeba przekazania projektu do branz specjalistycznych projektanci zmuszen są nadal wykonywac "krok do tyłu konwertując inteligentny model wielowymiarowy z pełną informacją o elementach projektu, na rysunki płaskie CAD, porzucając opracowane bazy danych. Specjaliści z wielu branż wspóttworzących pro- forced to change the design environment through legislation, tend to appreciate the advantages of the siction rather aproconsideri anu un complication and a purposeless change of the paterns established over the years

resenting the Royal Institute of British Architects claims that integration culture is the key to efficien implementation of technologies. These words, spoken in the context of merging the team associated with the project, perfectly describe the very idea behind BIM.

During the research, the level of designers' attiworking methods was measured. $93 \%$ of respondents answered that adapting the office to the needs of BIM adoption involves redefining and changing practices that have been established for years, changing habits and formalizing the flow of tasks and procedures - this is a difficult and timeconsuming process.

A complete integration of industries is the key to that can be tested in virtual reality. The implementation and testing of alternative solutions do no involve an increased amount of work as the mode updates all industries simultaneously.

Based on the above-mentioned research, it is clear that the British who, one could say, are being forced to change the design environment through the situation rather than consider it an unnecessary complication and a purposeless change of the patterns established over the years.

From this analysis emerges an image of BIM techniques designed to revolutionize the organizatio of work of a 21st-century design office, a place where the architect stops being a visionary and tion of the project. The architect takes full contro of each stage of the investment process, starting from the conceptual stage, through construction costing and cooperation at the construction site, to the coordination of the entire team involved in the

process.
Striving to fully integrate the design process, no terms of speed, accuracy, and scope of the project appears to be a guarantee of success on the market of modern, complex investments. Especially since having such requirements for architects is already becoming commonplace among investors. Standing at the threshold of such big changes that are already occurring in the neighboring countries, Western Europe it is obliged to am the standards of to the domestic conditions despite the lack of legislative orders. Otherwise, Polish designers may find themselves in a situation where they will not be able to compete with the modern design model not only for formal reasons but in particular in terms of speed, accuracy, and scope of the project.

Many Polish architects have already given technoloproject needs to be handed to specialist when the the designers are still forced to "take a step back" and convert the smart multidimensional model con- jekt nadal nie widzą potrzeby projektowania w przestrzeni wielowymiarowej (4D,5D,6D,7D) choć tendencja ta z roku na rok ulega przełamaniu.

Krok po kroku, w Polsce zbliża się moment, gdy na rynek wkroczą nowe pokolenia projektantów wychowanych $w$ czasach boomu informatycznego $i$ instalacje sanitarn czy elektryczne zaprojektowane całkowicie w wielowymiarowej przestrzeni modelu zbudowanego uprzednio przez architekta beda codziennościa. Projekty osiagna przez architekta bed a codzienoscia. Projekty osiaggn nistościa spotykan na placu budowy, a wiekszość koczyproblemów można bedzie przewidzieć już na etapie projektowania.

Zzybkie reagowanie na pojawiające się kolizje branż przypiesza proces projektowy, a jednocześnie zmniejsza koszty wykonawstwa i nie generuje przerw technicznych związanych ze zmianami w projekcie podczas budowy.

W czasach zwiększającej się presji napływającej z krajów ozwiniętych, na horyzoncie jawi się dzień, w którym projektowanie międzybranżowe w oparciu o metodolog BIM całkowicie zastąpi wirtualne deski kreślarskie zmieniając raz na zawsze sposób projektowania.

Aktualnie jest już pewne, że zalety projektowania zgodnie z metodologią BIM są znaczące. Testowanie najnowszych rozwiązan konstrukcyjnych czy instalacyjnych w oparciu o wirtualny model zdaje się byc nisko kosztowym i rozsądnym rozwiązaniem. Nadając modelowi unikalne parametry i lokalizując go $w$ warunkach bliskich rzeczywisty przetestować można wiele nowatorskich rozwiązań minmalizując ryzyko związane z ich zastosowaniem.

LITERATURA

[1] Azhar, S., Hein, M. and Sketo, B. Building Information Modeling: Be-
nefits, Risks and Challenges (2008), Proceedings of the 44 th ASC National Conference, Auburn, Alabama, USA.
Croceedings of the 44th ASC National [2] Anna Winstanley and Nigel Fraser of Lean BIM Strategies Limited pre-
sent a practical perspective. 2013. [4] Douglas C. Engelbart AUGMENTING HUMAN INTELLECT: A CONCEP-
TUAL FRAMEWORK Stanford Research Institute AFIPS Conference Proceedings of the 1968 Fall Joint Computer Conference, San Francisco, CA. 5] IFC format plików oparty na obiektach z modelu danych opracowanyc przez buildingSMART (dawniej International Alliance for Interoperability
IAl), aby utatwic wspotpracę w zakreseie architektury, inżynierii i budow ctwai przemystu, jest powszechnie estososwane w do wspótpracy w prog
mach BIIM modelujacccych informacie o budynku. [6] "NBS National BIM Report 2014" RiBAA Enterprises Ltd 1http://Www
thenbs.com/topics/BIM/articles/top10BIMQuestions.asp "The top 10 BIM questions" " r Stephen Hamil.
[7] http://Www.archdaily.com/302490/a-brief-history-of-bim/ lub Charles Ea-
stman - What is BIM? Data dostępu : 19.01.2015. taining all information about design elements to flat CAD drawings, abandoning the created databases. Specialist from many industries co-creating a project still do not see the need to design in a multidimensional space $4 \mathrm{D}, 5 \mathrm{D}$, Step by step, the moment is approaching in Poland when new generations of designers brought up in the time of an IT boom will enter the market and sanitary or electrical installations designed entirely in the multidimensional space of the model built by the architect will be commonplace. The projects will achieve an unImaginable precision of execution and compliance with It will a tso be possible to predict most of the clashes and problems at the design stage.

ashes of industries will peed up the design process. At the same time it reduces the costs of construction and does not generate technical breaks related to changes in the project during construction.

In times of an increasing pressure coming from develproach to design based on the BIM methodology will completely replace virtual drafting boards, changing the way designing works once and for all, appears on the horizon.

It is now certain that the advantages of design in accordance with the BIM methodology are significant. Testing the latest construction or installation solutions based on solution. By giving the model unique parameters, ing it in real-like conditions, we can test many innovative solutions and minimize the risks associated with their use.

\section{BIBLIOGRAPHY}

[1] Azhar, S., Hein, M. and Sketo, B., Building Information Mode-
ling: Benefits, , isks and Challenges (2008), Proceedings of the 44th SC National Conference Auburn, Alabama, USA. ted present a practitical perspecective.
[3] BIM strategy training for clients and consultants, London, 3 September 2013.
[4] Douglas. C. Engelbart AUGMENTING HUMAN INTELLECT:
A CONCETUAL RRAMEWORK Stanford Research Institute AFIPS
Conference Proceedings of the 1968 Fall Joint Computer Conferen-

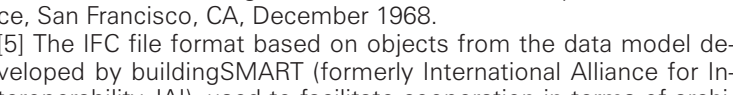
veloped by buildingSMART (formerly International Alliance for lin-
eroperability, All) used to facilitate cooperation in terms of arch
ecture, engineering, construction, and industry, is widely used for buildingS.
6] "NBS National BIM Report 2014" RIBA Enterprises Ltd 1http:// www.thenbs.com/topics/BIM/articles/top 10 BIM Questions.asp
"The top 10 BIM questions" Dr Stephen Hamil.

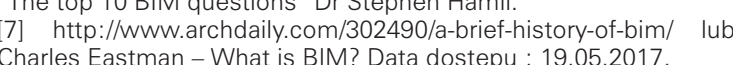

